\title{
Resistance to Meloidogyne incognita, Meloidogyne javanica and Pratylenchus brachyurus in sunflower cultivars adapted to the tropical region of Brazil
}

\author{
Waldir Pereira Dias ${ }^{1}$. Larissa Alexandra Cardoso Moraes ${ }^{1}$. \\ Claudio Guilherme Portela de Carvalho ${ }^{1}$. Maria Cristina Neves de Oliveira ${ }^{1}$. \\ Idenize Pedrina Orsini ${ }^{2} \cdot$ Regina Maria Villas Bôas Campos de Leite ${ }^{1}$
}

Received: 22 April 2016 / Accepted: 22 August 2016 / Published online: 20 September 2016

(C) Sociedade Brasileira de Fitopatologia 2016

\begin{abstract}
The continuous soybean-maize crop succession in the tropical region of Brazil has led to significant increases in the population size of root-knot (Meloidogyne incognita and M. javanica) and root-lesion nematodes (Pratylenchus brachyurus), which make soils unsuitable for soybean cropping. A greenhouse study was conducted to identify sunflower genotypes adapted to the tropical region of Brazil and that are resistant to $M$. incognita, $M$. javanica and/or $P$. brachyurus. Two experiments for each nematode were conducted in a completely randomized design with six replicates. Gall index was calculated from visual scores $(0-5)$ of gall intensity on roots for the root-knot nematode. Initial and final population density and reproduction factor were also measured for each nematode. Sunflower genotypes varied in resistance to the nematodes. Sunflower hybrids BRS 321 and BRS 323 were resistant to $M$. javanica and P. brachyurus and exhibited low gall index for $M$. incognita. The cultivars are good alternatives to using in the succession of soybean in nematode-infested areas of the tropical regions of Brazil. No sunflower genotype was identified as resistant to $M$. incognita and thus sunflower cropping is not indicated in areas infested with this nematode.
\end{abstract}

Keywords Helianthus annuus $\cdot$ Root-knot nematodes · Root-lesion nematode

Section Editor: C. Marcelo G. de Oliveira

Regina Maria Villas Bôas Campos de Leite regina.leite@embrapa.br

Embrapa Soja, 86001-970 Londrina, PR, Brazil

2 Universidade Estadual de Londrina, Londrina, PR, Brazil
In Brazil, soybean (Glycine max L.) is usually sown in October and November and harvested between January and March. The harvested area in the 2015/2016 growing season was approximately 33.1 million hectares (CONAB 2016). In Central Brazil, it is common to grow a second crop in the summer, to optimize the use of machinery and the available manpower, resulting in increased profit for the farmer. Maize (Zea mays L.) is usually a good option as a second crop sown in February/March in a total area of 9.9 million hectares (CONAB 2016).

The soybean-maize crop succession has led to significant increases in the size of populations of the root-knot (Meloidogyne incognita and Meloydogyne javanica) and root-lesion nematodes (Pratylenchus brachyurus), mainly in the tropics of central-western of Brazil (Silva et al. 2014; Franchini et al. 2014). Such increase is due to the ability of these nematodes in multiplying on both soybean and corn plants. Despite being an excellent host to these pathogens, the damage they cause on maize is little because most of the hybrids used in Brazil are tolerant. On the other hand, soybean is greatly affected by these pathogens. According to Franchini et al. (2014), losses in soybean crops can reach up to $50 \%$ in sandy soils with high populations of $P$. brachyurus.

The use of Crotalaria spectabilis or C. ochroleuca in succession or rotation with soybean has been the most effective measure for the control of root-knot and root-lesions nematodes in infested areas (Wang et al. 2002; McSorley et al. 2009). However, it is important to search for alternatives for the second cropping that contribute to nematode management and result in profit for farmers.

Sunflower (Helianthus annuus L.) cultivation is increasing in Brazil, with 111.5 thousand hectares in the 2015 season (CONAB 2016). However, there is an enormous potential for expansion as a second summer crop in the country's tropical region, where seasonal climate conditions are suitable for its cultivation - rainfall $(300-700 \mathrm{~mm}$ ) and temperature (22 to 
$27^{\circ} \mathrm{C}$ ) (INMET 2015; CONAB 2016). The potential for expansion is also driven by a growing demand for special oils for human consumption, for example, high oleic oil, and the country's demand for biofuel (Grunvald et al. 2008, 2014).

The effective control of nematodes depends largely on the use of resistant cultivars and crop rotation with a non-host plant (Rosa et al. 2013), but there is a lack of resistant genotypes that can be used as summer crops, especially to the rootknot nematodes. Sunflower cultivars that are adapted to the tropical region of Brazil and show good agronomic performance have been reported (Grunvald et al. 2008; Porto et al. 2008; Grunvald et al. 2014; Carvalho et al. 2015).

Generally, assessments of host resistance are based on measures of reproduction by counting nematodes in the new generation. The counted nematodes may be the reproducing females or their progeny (in cysts, egg masses or even as next generation invasive stages) (Perry and Moens 2006). The IAC Uruguai and Syn 045 sunflower cultivars resulted in a low increase or even reduction of $P$. brachyurus populations (Inomoto et al. 2006; Santana-Gomes et al. 2014). Rosa et al. (2013) found resistance to M. javanica on IAC Uruguai. However, the resistance levels of sunflower cultivars to root-knot and root-lesion nematodes has not been studied in detailed. Therefore, this study aimed at identifying sunflower genotypes that are adapted to tropical regions of Brazil and resistant to $M$. incognita, M. javanica and/or P. brachyurus, and can be grown following soybean in root-knot and/or rootlesion nematode-infested areas.

Six experiments, two for each nematode, were conducted in the greenhouse at Londrina, Paraná State, Brazil, from March to May 2015. The temperature during this period ranged from 17 to $36^{\circ} \mathrm{C}$. Each experiment was in a completely randomized design, with six replicates. Fourteen sunflower genotypes were selected for evaluation and included hybrids and open-pollinated varieties with high yield and adaption to the tropical region of the country (Grunvald et al. 2008; Porto et al. 2008; Grunvald et al. 2014; Carvalho et al. 2015). Parental lines CMSHA BR 01, CMSHA BR 02 and RHA BR 01 were also used in the second experiment with $M$. javanica. Soybean genotypes were used as resistant and susceptible checks: lines PI 595099 (resistant to M. incognita and M. javanica), Embrapa 20 (susceptible to $M$. incognita, M. javanica and P. brachyurus), CD 202 (resistant to $M$. incognita and susceptible to $M$. javanica and P. brachyurus) and BRS Celeste (susceptible to M. incognita and $P$. brachyurus and resistant to $M$. javanica). In the experiment with $M$. javanica, a resistant sunflower cultivar, IAC Uruguai (Rosa et al. 2013), was also included.

Inoculum of root-knot nematodes was obtained from pure populations of $M$. javanica and $M$. incognita multiplied in soybean Embrapa 20 (Doko RC) for about 60 days in the greenhouse. The population of $M$. incognita belonged to race 3 and was obtained from cotton plants. After this period, roots were carefully removed from the pots, washed with tap water to remove the adhering soil and, subsequently, grounded in a blender with sodium hypochlorite $0.5 \%$ (Boneti and Ferraz 1981) for eggs and $\mathrm{J}_{2}$ extraction. The resulting suspension was filtered through 200 and 500 mesh sieves. The retained material on the 200 mesh sieve was discarded and the eggs and $\mathrm{J}_{2}$ recovered from the 500 mesh sieve were transferred to a beaker and then quantified under the optical microscope using Peter's slide. The concentration of the suspension was standardized to 1,250 eggs and $\mathrm{J}_{2} / \mathrm{mL}$.

For P. brachyurus, a pure nematode population was multiplied in peanut (Arachis hypogaea) grown in the greenhouse for about three months. Thereafter, roots were collected, washed to remove the excessive soil and, subsequently, ground in a blender for extraction of juvenile and adult nematodes (Coolen and D'Herde 1972). The resulting suspension was filtered through 60 and 500 mesh sieves and the nematodes were collected in a beaker. The suspension was standardized to 125 nematodes $/ \mathrm{mL}$.

Seeds of sunflower genotypes and soybean were sown in sand, and three days after the emergence, seedlings (one per pot) were transplanted to 1.0 L-clay pots, containing substrate constituted of a mixture of soil and sand (1:3), previously autoclaved. Two days after transplanting, each seedling was inoculated with 5,000 eggs and $\mathrm{J}_{2}$ (root-knot nematode) or with 500 juveniles and adults (P. brachyurus). The inoculation was performed with the aid of an automatic pipette to insert the suspension of nematodes $(4.0 \mathrm{~mL})$ in a $2 \mathrm{~cm}$ deep hole open at the side of the seedling neck.

After 55 (root-knot nematodes) and 62 (root-lesion) days after inoculation, the aerial parts of the plants were cut and the root system of each plant was gently removed from the pot and washed with tap water to remove the adhering soil. For root-knot nematodes, the gall index (GI) was determined using a scale from 0 (absence) to 5 (maximum intensity) for the intensity of galls on roots. Differently from what was proposed by Taylor and Sasser (1978), in this study the galls were not counted; the score was assigned based only on visual symptoms on the roots.

Subsequently, roots were cut into $2 \mathrm{~cm}$ pieces, and eggs and $\mathrm{J}_{2}$ (root-knot nematode) and juveniles and adults (P. brachyurus) from each plant were quantified as previously described for the inoculum preparation. Based on the average nematode populations obtained from the different genotypes of soybean and sunflower, the reproduction factors (RF) of the respective nematodes were determined by the ratio between final population (FP) and initial population (IP) of nematodes (Oostenbrink 1966).

The data for each of the variables (GI and FP for root-knot nematodes and FP for root-lesion nematode) were subjected to analysis of variance and means were compared by the ScottKnott test at $5 \%$ probability, after checking the assumptions of normality and independence of errors and homogeneity of 
the residual variances of the model fitted for each experiment (Pimentel-Gomes 1985). Cultivars were also classified for their reaction to root-knot and root-lesion nematodes, based on the resistant factor: $\mathrm{RF}<1.0=$ resistance and $\mathrm{RF} \geq 1.0=$ susceptible (Oostenbrink 1966).

Significant differences $(P<0.01)$ were observed among genotypes and for the genotype $\mathrm{x}$ experiment interaction factors for both $M$. incognita and M. javanica (Table 1). Means of the variables differed among genotypes evaluated on each experiment based on the Scott-Knott test at $5 \%$ probability (Tables 2 and 3). For M. incognita, sunflower genotypes CF 101 and BRS G43 showed the lowest gall index, in both experiments, followed by BRS 321 and BRS 323 (Table 2). For FP, most genotypes showed gall index values similar to the soybean checks CD 202 (Experiment 1) and PI 595099 (Experiment 2). The lowest GI for M. javanica was found for BRS 321 and BRS 323 genotypes, similar to the soybean resistant check BRS Celeste, in both experiments (Table 3). However, these sunflower genotypes showed lower FP.

The reaction of soybean and sunflower genotypes used as resistant checks for root-knots nematodes was not consistent with previous knowledge (Tables 2 and 3 ). Soybean genotypes considered resistant to $M$. incognita (PI 595099 and CD 202) showed the lowest FP compared to the susceptible lines, but the RF values were $>1.0$, typical of a susceptible reaction (Oostenbrink 1966). For $M$. javanica, similar results were found for the resistant checks PI 595099 and BRS Celeste. Sunflower IAC Uruguai, previously reported as resistant (Rosa et al. 2013), showed RF > 1.0 and also high FP, thus being classified as susceptible in this study.
The non-confirmation of resistance of soybean checks to M. incognita may be due to the use of different races of the pathogen. In our study, the population of $M$. incognita belongs to race 3 and it was obtained from cotton plants, in which races 1 and 2 do not multiply (Taylor and Sasser 1978). The soybean resistance to this nematode can be race-specific as reported in okra (Abelmoschus esculentus L.) (McLeod et al. 1983). Several accesses of okra resistant to race 3 of M. incognita reacted as susceptible when inoculated with race 1 (Fassuliotis 1985). Races were still not described for M. javanica. Additional studies using different sources of inoculum will be needed.

The RFs of sunflower genotypes evaluated for M. incognita ranged from 16.5 (CF 101 and BRS 323) to 73.3 (NEON) (Table 2), which does not allow classifying them as resistant (Oostenbrink 1966). However, CF 101, BRS G43, BRS 323, BRS 321 and MG 360 genotypes showed low GI ranging from 1.0 to 2.2, suggesting that, despite their ability to multiply the pathogen, the damage is low even at levels of infection that would lead to economic losses in other varieties.

Since the CF 101, BRS G43, BRS 323, BRS 321 and MG 360 genotypes allow $M$. incognita to reproduce, they are not suitable for planting in infested areas, especially following soybean, because nematode population density in the soil would build up for the next season. Sunflower reaction is very similar to that of maize (Asmus et al. 2000; Dias et al. 2010). Although there are maize genotypes that can tolerate $M$. incognita damage, there are no sources of resistance in maize germplasm. In infested areas, growers should sow non-host species, such as $C$. spectabilis and C. ochroleuca,
Table 1 Analysis of variance for gall index (GI) and final population (FP) of Meloidogyne incognita, Meloidogyne javanica and Pratylenchus brachyurus evaluated for sunflower resistance in greenhouse experiments

\begin{tabular}{|c|c|c|c|}
\hline \multirow[t]{2}{*}{ Source of variation } & \multirow{2}{*}{$\begin{array}{l}\text { Degrees of } \\
\text { freedom }\end{array}$} & \multicolumn{2}{|c|}{ Mean squares } \\
\hline & & GI & $\mathrm{FP}$ \\
\hline \multicolumn{4}{|l|}{ M. incognita } \\
\hline Genotype (G) & 17 & $14.26^{* *}$ & $140302877235.82^{* *}$ \\
\hline Experiment (E) & 1 & $7.78^{* * *}$ & $269148380046.29^{* * *}$ \\
\hline Gx E & 17 & $3.28^{* * *}$ & $46721850438.45^{* *}$ \\
\hline Error & 180 & 0.46 & 4576489120.37 \\
\hline \multicolumn{4}{|l|}{ M. javanica } \\
\hline Genotype (G) & 18 & $15.39^{* *}$ & $116955175461.98^{* * *}$ \\
\hline Experiment (E) & 1 & $2.66^{* *}$ & $212785278935.18^{* *}$ \\
\hline $\mathrm{G} \times \mathrm{E}$ & 18 & $1.21^{* *}$ & $33772819644.98^{* * *}$ \\
\hline Error & 191 & 0.57 & 6332601412.96 \\
\hline \multicolumn{4}{|l|}{ P. brachyurus } \\
\hline Genotype (G) & 16 & - & $2737598.03^{* *}$ \\
\hline Experiment (E) & 1 & - & $63529.41^{\mathrm{ns}}$ \\
\hline $\mathrm{G} \times \mathrm{E}$ & 16 & - & $24362.74^{\mathrm{ns}}$ \\
\hline Error & 170 & - & 221098.03 \\
\hline
\end{tabular}

** significant at $1 \%$ by the $\mathrm{F}$ test; ${ }^{\mathrm{ns}}$ non-significant at $5 \%$ by the $\mathrm{F}$ test 
Table 2 Gall index (GI), final population (FP), reproduction factor (RF) and reaction (RE) of soybean and sunflower genotypes to Meloidogyne incognita

\begin{tabular}{|c|c|c|c|c|c|c|c|c|}
\hline \multirow[t]{2}{*}{ Genotypes } & \multicolumn{4}{|c|}{ Experiment 1} & \multicolumn{4}{|c|}{ Experiment 2} \\
\hline & $\mathrm{GI}^{\mathrm{a}, \mathrm{b}}$ & $\mathrm{FP}^{\mathrm{b}}$ & $\mathrm{RF}^{\mathrm{c}}$ & $R E^{d}$ & $\mathrm{GI}^{\mathrm{a}, \mathrm{b}}$ & $\mathrm{FP}^{\mathrm{b}}$ & $\mathrm{RF}^{\mathrm{c}}$ & $R E^{\mathrm{d}}$ \\
\hline \multicolumn{9}{|l|}{ Soybean } \\
\hline BRS Celeste & $4.3 \mathrm{a}$ & $243900 \mathrm{~b}$ & 48.8 & $\mathrm{~S}$ & $4.8 \mathrm{a}$ & $537083 \mathrm{a}$ & 107.4 & S \\
\hline CD 202 & $3.3 \mathrm{~b}$ & $104583 \mathrm{~d}$ & 20.9 & $\mathrm{~S}$ & $4.5 \mathrm{a}$ & $456916 \mathrm{~b}$ & 91.4 & S \\
\hline Embrapa 20 & $4.8 \mathrm{a}$ & $458400 \mathrm{a}$ & 91.7 & $\mathrm{~S}$ & $4.7 \mathrm{a}$ & $412500 \mathrm{~b}$ & 82.5 & S \\
\hline PI 595099 & $2.0 \mathrm{c}$ & $215000 \mathrm{~b}$ & 43.0 & S & $1.8 \mathrm{~d}$ & $215583 \mathrm{c}$ & 43.1 & S \\
\hline \multicolumn{9}{|l|}{ Sunflower } \\
\hline ADV 5504 & $4.2 \mathrm{a}$ & $69250 \mathrm{~d}$ & 13.9 & $\mathrm{~S}$ & $4.2 \mathrm{a}$ & $139166 \mathrm{c}$ & 27.8 & S \\
\hline Aguara 4 & $3.2 \mathrm{~b}$ & $151900 \mathrm{c}$ & 30.4 & S & $2.7 \mathrm{c}$ & $110833 \mathrm{c}$ & 22.2 & S \\
\hline Aguará 6 & $3.7 \mathrm{~b}$ & $47250 \mathrm{~d}$ & 9.5 & S & $3.2 \mathrm{c}$ & $131916 \mathrm{c}$ & 26.4 & S \\
\hline BRS 321 & $1.8 \mathrm{c}$ & $32583 \mathrm{~d}$ & 6.5 & S & $2.0 \mathrm{~d}$ & $111500 \mathrm{c}$ & 22.3 & S \\
\hline BRS 323 & $1.7 \mathrm{c}$ & $36000 \mathrm{~d}$ & 7.2 & S & $1.8 \mathrm{~d}$ & $82416 \mathrm{c}$ & 16.5 & S \\
\hline BRS G43 & $1.8 \mathrm{c}$ & $45700 \mathrm{~d}$ & 9.1 & S & $1.3 \mathrm{e}$ & $121500 \mathrm{c}$ & 24.3 & S \\
\hline CF 101 & $1.8 \mathrm{c}$ & $148700 \mathrm{c}$ & 29.7 & S & $1.0 \mathrm{e}$ & $82583 \mathrm{c}$ & 16.5 & S \\
\hline Embrapa 122 & $4.0 \mathrm{~b}$ & $85416 \mathrm{~d}$ & 17.1 & S & $4.3 \mathrm{a}$ & $84833 \mathrm{c}$ & 17.0 & S \\
\hline Helio 250 & $4.2 \mathrm{a}$ & $173666 \mathrm{c}$ & 34.7 & S & $4.8 \mathrm{a}$ & $172500 \mathrm{c}$ & 34.5 & S \\
\hline Helio 251 & $4.3 \mathrm{a}$ & $67166 \mathrm{~d}$ & 13.4 & S & $3.0 \mathrm{c}$ & $101000 \mathrm{c}$ & 20.2 & S \\
\hline M 734 & $4.7 \mathrm{a}$ & $128333 \mathrm{c}$ & 25.7 & S & $2.8 \mathrm{c}$ & $133583 \mathrm{c}$ & 26.7 & S \\
\hline MG 360 & $5.0 \mathrm{a}$ & $161000 \mathrm{c}$ & 32.2 & S & $2.2 \mathrm{~d}$ & $122833 \mathrm{c}$ & 24.6 & S \\
\hline NEON & $3.5 \mathrm{~b}$ & $50200 \mathrm{~d}$ & 10.0 & S & $3.7 \mathrm{~b}$ & $366666 \mathrm{~b}$ & 73.3 & $\mathrm{~S}$ \\
\hline SYN 045 & $4.7 \mathrm{a}$ & $57166 \mathrm{~d}$ & 11.4 & $\mathrm{~S}$ & $3.2 \mathrm{c}$ & $150833 \mathrm{c}$ & 30.2 & $\mathrm{~S}$ \\
\hline
\end{tabular}

${ }^{\mathrm{a}} \mathrm{GI}=$ visual score $(0-5)$ for the intensity of galls on roots; ${ }^{\mathrm{b}}$ Means followed by the same letter in each column do not differ significantly by the Scott-Knott test at $5 \%$ probability; ${ }^{\mathrm{c}} \mathrm{RF}=$ final/initial population; ${ }^{\mathrm{d}}$ Reaction based on Oostenbrink (1966): resistant $(\mathrm{R})(\mathrm{RF}<1.0)$ and susceptible $(\mathrm{S})(\mathrm{RF} \geq 1.0)$ or certain resistant genotypes of millet (Pennisetum glaucum L.), oat (Avena sativa L.), wheat (Triticum aestivum L.), turnip (Raphanus sativus L.) or other resistant crops (Wang et al. 2004; McSorley 2011; Kokalis-Burelle et al. 2013).

The RF of sunflower genotypes to $M$. javanica ranged from 0.2 (BRS 321 and RHA BR 01-A) to 73.4 (M 734) (Table 3). Genotypes BRS 321, BRS 323 and RHA BR 01-A were classified as resistant $(\mathrm{RF}<1.0)$ and the others were susceptible ( $R F \geq 1.0)$ according to Oostenbrink (1966). These resistant genotypes also presented low GI. Genotypes BRS 321 and BRS 323 are simple hybrids derived from crosses of the same male parent (RHA BR 01) with female parents CMSHA BR 01 and CMSHA BR 02, respectively. Results show that the resistance of these two hybrids was inherited from the male parent. However, despite having the same male parent, the multiplication of $M$. javanica in BRS $321(\mathrm{RF}=0.2)$ was slightly lower than in the BRS $323(\mathrm{RF}=1.1)$ (Table 3).

Considering the male parent RHA BR 01, plants phenotypically distinct with respect to plant height have been observed in the field. Plants with high height (RHA BR 01-B) showed GI (3.3) and RF (20.4) which were far superior to those presented by plants with low height (RHA BR $01-A)(G I=1.0$ and $R F=0.2)$ (Table 3). Differences in plant height can also be observed for both hybrids BRS
321 and BRS 323, suggesting the existence of withinhybrid genetic variability that reflected in different RF for M. javanica. Among BRS 323 plants, the presence of one plant with high height $(\mathrm{RF}=3.4)$ increased mean RF to 1.1. All BRS 321 plants showed low height. It is likely that for both the male parent as hybrids BRS 321 and BRS 323, an association exists between the plant height and reaction to $M$. javanica. Plants with lower height tend to multiply less (lower RF). Sunflower breeding programs should not include the RHA BR 01-B line, which would result in hybrids with RF to $M$. javanica near zero and thus become an option for cultivation in infested areas.

The search for resistant genotypes is critical for plant nematode management, due to the difficulties to eradicate the pathogen associated with resistance mechanisms, which allow the eggs to remain viable for long periods in the soil. As they present parthenogenetic reproduction, which contributes to reducing genetic variability, sources of resistance to $M$. javanica tend to be more durable compared to nematodes with other types of sexual reproduction, such as Heterodera glycines (Taylor and Sasser 1983). This increases the value of using a resistant male parent in sunflower breeding programs to produce root-knot resistant genotypes. 
Table 3 Gall index (GI), final population (FP), reproduction factor (RF) and reaction (RE) of soybean and sunflower genotypes to Meloidogyne javanica

\begin{tabular}{|c|c|c|c|c|c|c|c|c|}
\hline \multirow[t]{2}{*}{ Genotypes } & \multicolumn{4}{|c|}{ Experiment 1} & \multicolumn{4}{|c|}{ Experiment 2} \\
\hline & $\mathrm{GI}^{\mathrm{a}, \mathrm{b}}$ & $\mathrm{FP}^{\mathrm{b}}$ & $\mathrm{RF}^{\mathrm{c}}$ & $R E^{d}$ & $\mathrm{GI}^{\mathrm{a}, \mathrm{b}}$ & $\mathrm{FP}^{\mathrm{b}}$ & $\mathrm{RF}^{\mathrm{c}}$ & $\mathrm{RE}^{\mathrm{d}}$ \\
\hline \multicolumn{9}{|l|}{ Soybean } \\
\hline BRS Celeste & $2.0 \mathrm{c}$ & $163083 \mathrm{~b}$ & 32.6 & $\mathrm{~S}$ & $1.9 \mathrm{~b}$ & 209416 c & 41.9 & $\mathrm{~S}$ \\
\hline CD 202 & $4.7 \mathrm{a}$ & $304000 \mathrm{a}$ & 60.8 & S & $4.7 \mathrm{a}$ & $382916 \mathrm{~b}$ & 76.6 & S \\
\hline Embrapa 20 & $4.8 \mathrm{a}$ & $232583 \mathrm{a}$ & 46.5 & S & $4.8 \mathrm{a}$ & $451416 \mathrm{a}$ & 90.3 & S \\
\hline PI 595099 & $2.0 \mathrm{c}$ & 89333 b & 17.9 & $\mathrm{~S}$ & $2.0 \mathrm{a}$ & $79333 \mathrm{~d}$ & 15.9 & $\mathrm{~S}$ \\
\hline \multicolumn{9}{|l|}{ Sunflower } \\
\hline ADV 5504 & $4.0 \mathrm{~b}$ & $116500 \mathrm{~b}$ & 23.3 & $\mathrm{~S}$ & $5.0 \mathrm{a}$ & $343083 \mathrm{~b}$ & 68.6 & $\mathrm{~S}$ \\
\hline Aguara 4 & $5.0 \mathrm{a}$ & $279200 \mathrm{a}$ & 55.8 & S & $4.5 \mathrm{a}$ & $158166 \mathrm{c}$ & 31.6 & S \\
\hline Aguará 6 & $4.0 \mathrm{~b}$ & $90433 \mathrm{~b}$ & 18.1 & S & $4.5 \mathrm{a}$ & $233750 \mathrm{c}$ & 46.8 & S \\
\hline BRS 321 & $1.5 \mathrm{c}$ & $1080 \mathrm{c}$ & 0.2 & $\mathrm{R}$ & $1.5 \mathrm{~b}$ & $1833 \mathrm{~d}$ & 0.4 & $\mathrm{R}$ \\
\hline BRS 323 & $1.2 \mathrm{c}$ & $5520 \mathrm{c}$ & 1.1 & $\mathrm{R}$ & $1.8 \mathrm{~b}$ & $5000 \mathrm{~d}$ & 1.0 & $\mathrm{R}$ \\
\hline BRS G43 & $4.0 \mathrm{~b}$ & 91966 b & 18.4 & S & $4.0 \mathrm{a}$ & $187500 \mathrm{c}$ & 37.5 & $\mathrm{~S}$ \\
\hline CF 101 & $5.0 \mathrm{a}$ & $285266 \mathrm{a}$ & 57.1 & S & $4.0 \mathrm{a}$ & $191833 \mathrm{c}$ & 38.4 & S \\
\hline Embrapa 122 & $4.0 \mathrm{~b}$ & $121833 \mathrm{~b}$ & 24.4 & $\mathrm{~S}$ & $4.7 \mathrm{a}$ & $209000 \mathrm{c}$ & 41.8 & $\mathrm{~S}$ \\
\hline Helio 250 & $4.4 \mathrm{~b}$ & $210766 \mathrm{a}$ & 42.2 & $\mathrm{~S}$ & $4.2 \mathrm{a}$ & $239750 \mathrm{c}$ & 48.0 & $\mathrm{~S}$ \\
\hline Helio 251 & $4.3 \mathrm{~b}$ & $151666 \mathrm{~b}$ & 30.3 & $\mathrm{~S}$ & $4.5 \mathrm{a}$ & $231916 \mathrm{c}$ & 46.4 & S \\
\hline IAC Uruguai & $4.5 \mathrm{~b}$ & $231347 \mathrm{a}$ & 46.2 & $\mathrm{~S}$ & $4.2 \mathrm{a}$ & $215432 \mathrm{c}$ & 43.0 & S \\
\hline M 734 & $5.0 \mathrm{a}$ & $366866 \mathrm{a}$ & 73.4 & $\mathrm{~S}$ & $4.0 \mathrm{a}$ & $308416 b$ & 61.7 & S \\
\hline MG 360 & $4.8 \mathrm{a}$ & 257466 a & 51.5 & $\mathrm{~S}$ & $4.3 \mathrm{a}$ & $234916 \mathrm{c}$ & 47.0 & $\mathrm{~S}$ \\
\hline NEON & $3.3 \mathrm{~b}$ & $74700 \mathrm{~b}$ & 14.9 & $\mathrm{~S}$ & $4.8 \mathrm{a}$ & $274833 \mathrm{c}$ & 55.0 & $\mathrm{~S}$ \\
\hline SYN 045 & $3.3 \mathrm{~b}$ & $99066 \mathrm{~b}$ & 19.8 & $\mathrm{~S}$ & $4.8 \mathrm{a}$ & $278166 \mathrm{c}$ & 55.6 & $\mathrm{~S}$ \\
\hline \multicolumn{9}{|l|}{ Parental lines $\mathrm{e}$} \\
\hline CMSHA BR 01 & & & & & 3.7 & 169083 & 33.8 & $\mathrm{~S}$ \\
\hline CMSHA BR 02 & & & & & 4.5 & 154853 & 31.0 & $\mathrm{~S}$ \\
\hline RHA BR 01A & & & & & 1.0 & 975 & 0.2 & $\mathrm{R}$ \\
\hline RHA BR 01B & & & & & 3.3 & 101917 & 20.4 & $\mathrm{~S}$ \\
\hline
\end{tabular}

${ }^{\mathrm{a}} \mathrm{GI}=$ visual score $(0-5)$ for the intensity of galls on roots; ${ }^{\mathrm{b}}$ Means followed by the same letter in each column do not differ significantly by the Scott-Knott test at $5 \%$ probability; ${ }^{\mathrm{c}} \mathrm{RF}=$ final/initial population; ${ }^{\mathrm{d}}$ Reaction based on Oostenbrink (1966): resistant $(\mathrm{R})(\mathrm{RF}<1.0)$ and susceptible $(\mathrm{S})(\mathrm{RF} \geq 1.0)$; ${ }^{\mathrm{e}}$ results of one experiment
As for $P$. brachyurus, significant differences in FP were observed $(P<0.01)$ among genotypes, but not for genotype $\mathrm{x}$ experiment interaction. Thus, FP means of the two experiments were compared based on a Scott-Knott test (Tables 1 and 4). All sunflower genotypes showed similar FP means, and generally lower than those obtained from soybean susceptible checks (Table 4).

According to Oostenbrink (1966), all tested sunflower genotypes were classified as resistant to $P$. brachyurus (Table 4), since RF ranged from 0.1 (CF 101, BRS 321, BRS G43, Aguará 06 and NEON) to 0.5 (Syn 045). For susceptible soybean checks, RF scored 1.9 (Embrapa 20), 2.4 (202 CD) and 2.9 (BRS Celeste). Since sunflower genotypes originated from different breeding programs, thus representing a wide genetic variability, our data suggest that although it is not immune $(\mathrm{RF}=0)$, sunflower is a poor host of $P$. brachyurus, corroborating previous reports (Charchar and Huang 1981; SantanaGomes et al. 2014).

Presently, there is no soybean and corn cultivar resistant to root-lesion nematode, which explains the very high population size of $P$. brachyurus in the tropical region of Brazil. In sandy textured soils $(<15.0 \%$ clay), soybean cultivation is not economically feasible (Franchini et al. 2014). The most widely adopted strategy is to intercrop soybean with immune plant
Table 4 Final population (FP), reproduction factor $(\mathrm{RF})$ and reaction $(\mathrm{RE})$ of soybean and sunflower genotypes to Pratylenchus brachyurus

\begin{tabular}{llll}
\hline Genotypes & $\mathrm{FP}^{\mathrm{a}}$ & $\mathrm{RF}^{\mathrm{b}}$ & $\mathrm{RE}^{\mathrm{c}}$ \\
\hline Soybean & & & \\
CD 202 & $1200 \mathrm{a}$ & 0.1 & $\mathrm{~S}$ \\
BRS Celeste & $1450 \mathrm{a}$ & 0.1 & $\mathrm{~S}$ \\
Embrapa 20 & $950 \mathrm{a}$ & 0.2 & $\mathrm{~S}$ \\
Sunflower & & & \\
ADV 5504 & $150 \mathrm{~b}$ & 0.3 & $\mathrm{R}$ \\
Aguará 04 & $150 \mathrm{~b}$ & 0.3 & $\mathrm{R}$ \\
Aguará 06 & $50 \mathrm{~b}$ & 0.1 & $\mathrm{R}$ \\
BRS 321 & $50 \mathrm{~b}$ & 0.1 & $\mathrm{R}$ \\
BRS 323 & $100 \mathrm{~b}$ & 0.2 & $\mathrm{R}$ \\
BRS G43 & $50 \mathrm{~b}$ & 0.1 & $\mathrm{R}$ \\
CF 101 & $50 \mathrm{~b}$ & 0.1 & $\mathrm{R}$ \\
Embrapa 122 & $200 \mathrm{~b}$ & 0.4 & $\mathrm{R}$ \\
Helio 250 & $150 \mathrm{~b}$ & 0.3 & $\mathrm{R}$ \\
HELIO 251 & $200 \mathrm{~b}$ & 0.4 & $\mathrm{R}$ \\
M 734 & $100 \mathrm{~b}$ & 0.2 & $\mathrm{R}$ \\
MG 360 & $150 \mathrm{~b}$ & 0.3 & $\mathrm{R}$ \\
NEON & $50 \mathrm{~b}$ & 0.1 & $\mathrm{R}$ \\
SYN 045 & $250 \mathrm{~b}$ & 0.5 & $\mathrm{R}$ \\
\hline
\end{tabular}

Average of two tests; ${ }^{a}$ Means followed by the same letter in each column do not differ significantly by the Scott-Knott test at $5 \%$ probability; ${ }^{\mathrm{b}} \mathrm{RF}=$ final/initial population; ${ }^{\mathrm{c}}$ Reaction based on Oostenbrink (1966): resistant $(\mathrm{R})(\mathrm{RF}<1.0)$ and susceptible (S) $(\mathrm{RF} \geq 1.0)$ 
species, such as $C$. spectabilis and C. ochroleuca, or unfavorable hosts of the nematode, such as some millet genotypes.

The replacement of Crotalaria by sunflower genotypes with RF close to zero (Table 4) for P. brachyurus may be economically advantageous for farmers and help to reduce the risk of nematode damage. In areas with dual infestation (P. brachyurus and M. javanica), a suitable alternative is to use high-yielding BRS 321 and BRS 323 sunflower hybrids, which are resistant to both pathogens and adapted to the tropics (Grunvald et al. 2008; Porto et al. 2008; Grunvald et al. 2014; Carvalho et al. 2015). On the other hand, in areas infested with $P$. brachyurus and M. incognita, sunflower is not indicated since there is no sunflower resistant to the latter species. In summary, this study provides useful information on the reaction of sunflower genotypes adapted to tropical regions of Brazil to root-knot and root-lesion nematodes. Sunflower hybrids BRS 321 and BRS 323 are interesting options to crop in succession to soybean in areas with a dual infestation of $P$. brachyurus and M. javanica but not when M. incognita is present.

\section{References}

Asmus GL, Ferraz LCCB, Glória BA (2000) Alterações anatômicas em raízes de milho (Zea mays) parasitadas por Meloidogyne javanica. Nematropica 30:33-39

Boneti JIS, Ferraz S (1981) Modificação do método de Hussey e Barker para extração de ovos de Meloidogyne exigua de cafeeiro. Fitopatol Bras 6:553

Carvalho CGP, Ozawa EKM, Amabile RF, Godinho VPC, Gonçalves SL, Ribeiro JL, Seifert AL (2015) Adaptabilidade e estabilidade de genótipos de girassol resistentes a imidazolinonas em cultivos de segunda safra. Braz J Agric Res 10:1-7

Charchar JM, Huang CS (1981) Círculo de hospedeiras de Pratylenchus brachyurus. III - Plantas diversas. Fitopatol Bras 6:469-473

CONAB (2016) Acompanhamento de safra brasileira: grãos, safra 2015/16, sétimo levantamento. Available at. http://www.conab. gov.br/OlalaCMS/uploads/arquivos/16 $\begin{array}{llllll}04 & 07 & 10 & 39 & 11\end{array}$ boletim_graos_abril_2016.pdf Accessed 14 A $\mathrm{pr} 201 \overline{6}$

Coolen WA, D'Herde CJ (1972) A method for the quantitative extraction of nematodes from plant tissue. State Agricultural Research Centre, Ghent

Dias WP, Freitas VM, Ribeiro NR, Moita AW, Carneiro RMDG (2010) Reação de genótipos de milho a Meloidogyne mayaguensis e M. ethiopica. Nematol Bras 34:98-104

Fassuliotis G (1985) The role of the nematologist on the development of resistant cultivars. In: Sasser JN, Carter CC (eds) An advanced treatise on Meloidogyne: biology and control. North Carolina State University, Raleigh, pp 233-240

Franchini JC, Debiasi H, Dias WP, Ramos EU Jr, Silva JFV (2014) Perda de produtividade da soja em área infestada por nematoide das lesões radiculares na região médio norte do Mato Grosso. In: Bernardi ACC, Naime JM, Resende AV, Bassoi LH, Inamasu RY (eds) Agricultura de precisão: resultados de um novo olhar. Embrapa, Brasília, pp 274-278

Grunvald AK, Carvalho CGP, Amabile RF, Godinho VPC, Oliveira ACB, Ramos NP (2014) Adaptability and stability of conventional and high oleic sunflower genotypes cultivated in Central Brazil. Genom Quan Genet 8:7-15

Grunvald AK, Carvalho CGP, Oliveira ACB, Andrade CAB (2008) Adaptabilidade e estabilidade de genótipos de girassol no Brasil Central. Pesq Agrop Bras 43:1483-1493

INMET (2015) Banco de dados meteorológicos para ensino e pesquisa. Available at: http://www.inmet.gov.br/portal/index.php?r= bdmep/bdmep. Accessed 27 Mar 2015

Inomoto MM, Motta LCC, Machado ACZ, Sazaki CSS (2006) Reação de dez coberturas vegetais a Pratylenchus brachyurus. Nematol Bras 30:151-157

Kokalis-Burelle N, Butler DM, Rosskopf EN (2013) Evaluation of cover crops with potential for use in anaerobic soil disinfestation (ASD) for susceptibility to three species of Meloidogyne. J Nematol 45: $272-278$

McLeod JM, Witcher W, Epps WM (1983) Resistance of okra plant introductions to root-knot nematode and Fusarium wilt. HortSci $18: 249-250$

McSorley R (2011) Assessment of rotation crops for management of rootknot nematodes (Meloidogyne spp.) in the southeastern United States. Nematropica 41:200-214

McSorley R, Seal DR, Klassen W, Wang KH, Hooks CRR (2009) Nontarget effects of sunn hemp and marigold cover crops on the soil invertebrate community. Nematropica 39:235-245

Oostenbrink R (1966) Major characteristics of the relation between nematodes and plants. Mededeelingen Landbouwhoogeschool 66:1-46

Perry RN, Moens M (2006) Plant Nematology. CAB International, Wallingford

Pimentel-Gomes F (1985) Curso de Estatística Experimental. ESALQ, Piracicaba

Porto WS, Carvalho CGP, Pinto RJB, Oliveira MF, Oliveira ACB (2008) Evaluation of sunflower cultivars for central Brazil. Sci Agric 65: 139-144

Rosa JMO, Westerich JN, Wilcken SRS (2013) Reprodução de Meloidogyne javanica em olerícolas em plantas utilizadas na adubação verde. Trop P1 Pathol 38:133-141

Santana-Gomes SM, Dias-Arieira CR, Biela F, Cardoso MR, Fontana LF, Puerari HH (2014) Crop succession in the control of Pratylenchus brachyurus in soybean. Nematropica 44:200-206

Silva C, Silva RA, Vale WG, Mello ACT (2014) Reação de cultivares de girassol (Helianthus annuus L.) a Meloidogyne incognita raça 3 e Meloidogyne javanica. Glob Sci Tech 7:7-15

Taylor AL, Sasser JN (1978) Biology, identification and control of rootknot nematodes. North Carolina State University, Raleigh

Taylor AL, Sasser JN (1983) Biología, identificación y control de los nematodos del nódulo de la raíz (espécies de Meloidogyne). North Carolina State University, Raleigh

Wang KH, McSorley R, Gallaher RN (2004) Effect of winter cover crops on nematode population levels in North Florida. J Nematol 36:517523

Wang KH, Sipes BS, Schmitt DP (2002) Crotalaria as a cover crop for nematode management: a review. Nematropica 32:35-57 